\title{
Multiphasic Model of Egg Production in Laying Hens
}

\author{
Luc Kieu Minh, Shunzo Miyoshi and Takatsugu Mitsumoto \\ Obihiro University of Agriculture and Veterinary Medicine \\ Inada, Obihiro, Hokkaido, 080
}

\begin{abstract}
Egg production in laying herıs was characterized by clutches. This study sought to examine the variability of the clutch characteristics and predictability of annual egg production by the multiphasic model of KoOPS and GROSSMAN (1992) with consideration of internal laying.

Oviposition time of 135 and 123 hens in high and low lines, respectively, of a population divergently selected for yolk-albumen ratio, wree observed at four stages of a laying period. Observation duration in each stage was about 30 days. Clutch characteristics considered in this study were LAG (mean lag of oviposition time within clutch) and DELAY (mean delay of pause day between clutches) estimated by a multiphasic model, rate of internal laying (IP), the number of clutches $(\mathrm{CN})$, average length of clutches (CL) and average size of clutches (CS).

LAG in both lines did not significantly vary over the four observed stages. DELAY, IP, and CN markedly increased, while CL and CS significantly decreased by stages in both lines. LAG in high line was significantly shorter than that in low line, which suggested that egg production in high line should be higher than that in low line. However, because the rate of internal laying in high line was higher than that in low line, the egg production in two lines was not significantly different.

Correlation of LAG with CN was high and positive, and that with CL and CS was medium and negative. LAG and IP showed negative correlation resulting from the inclusion of internal laying in the clutch definition.

The information of clutch characteristics in stages 1 and 2 at 120 and 188 days from onset of lay, respectively, was used to predict egg number of individual hens for the periods of 270 and 360 days of egg production by the multiphasic model. Mean of predicted values was about 35 eggs higher than that of actual number of eggs with correlation coefficients from 0.6 to 0.8 .
\end{abstract}

(Jpn. Poult. Sci., 32 : 161-168, 1995)

Key words : multiphasic model, clutch characteristics, egg production prediction, oviposition time, laying hen

\section{Introduction}

The development of mathematical models of egg production may not only be of potential use for producers to forecast income and flock performance but also describe an alternative method in genetic evaluation for poultry breeding progams (WoOd, 1967; McMillan et al., 1970 a, b ; McNally, 1971 ; Adam and Bell, 1980 ; YANG et al., 1989). The goodness of fit of these models is excellent when fitted to the data of the flock even to such small groups as dam and sire families. However, in the case of prediction of egg production of individual hens these models do not show superior applicability with coefficients of determination ranging from 0.0 to 0.97 (GAvorA et al., 1982 ; McMillan et al., 1986). 
A multiphasic model of Koops and Grossman (1992) has firstly been suggested to characterize egg production of individual hens by clutch characteristics, LAG and DELAY, where LAG is mean lag of oviposition time within clutch and DELAY is mean delay of pause day between clutches. LAG estimated by the multiphasic model is expected to be the best indicator of egg production. However, it is better to understand whether LAG is a variable or a constant over a whole period when LAG is used to predict egg production from early partial records (KoOPS and GROSSMAN, 1992).

The purpose of this paper is to examine the variability of clutch characteristics, and predictability of annual egg production from early partial records by the multiphasic model.

\section{Materials and methods}

Data were obtained from White Leghorn population of two selected lines. These lines were founded on a divergent selection for high and low yolk-albumen ratio in 12 generations since 1970, and relaxed selection from generation 13 (Miтsumoto and MiYoshi, 1989). The hens were housed in individual cages at an age of 150 days with light-dark regime about $14 \mathrm{hr} / 10 \mathrm{hr}$. Oviposition time was observed every one hour from $5: 30$ A.M. to $6: 30$ P.M. and recorded to the nearest half hour. Four observed stages of laying period and the number of recorded hens at each stage used in this study are shown in Table 1. Egg production (EP) data were recorded daily for individual hens, and hen-day egg production (egg number) was calculated for the two stages of egg production, one from the onset of lay to 270th day of EP, and another from the onset of lay to 360th day of EP. Rate of internal laying (IP), the number of clutches $(\mathrm{CN})$, average length of clutches (CL) and average size of clutches (CS) were calculated from the data of oviposition time for each hen.

Egg production is characterized by the number of eggs within a clutch and pause day between clutches. Each clutch consists of consecutively laid eggs or eggs laid in the sequence and internally laid eggs (GILBERT and Wood-Gush, 1971 ; NALBAndov and OpEL, 1974). Table 2 illustrates oviposition patterns and clutch formation. Clutch, internal laying, and pause day were determined from the oviposition time of each hen. It was obvious that egg production of the hens with no internal laying depended on intra-clutch interval and length of pause day.

Table 1. Number of hens recorded for oviposition time at four stages

\begin{tabular}{lcrrrr}
\hline & No. of hens & \multicolumn{4}{c}{ Observation stage } \\
\cline { 3 - 6 } housed & 135 & 125 & 120 & 115 & 104 \\
\hline High (H) & 123 & 118 & 106 & 98 & 96 \\
Low (L) & 258 & 243 & 226 & 213 & 200 \\
Total & & & & \\
\hline Average day from first egg at & 120 & 188 & 256 & 285 \\
which observation began & 25 & 30 & 30 & 30 \\
Observation duration (day) & & & & \\
\hline
\end{tabular}


Table 2. The illustration of oviposition patterns and the clutch formation of four typical hens

\begin{tabular}{cccccccccccccc}
\hline \hline Hen No. & Day & 1 & 2 & 3 & 4 & 5 & 6 & 7 & 8 & 9 & 10 & 11 & 12 \\
\hline \multirow{2}{*}{407} & PE & $\bigcirc$ & $\bigcirc$ & $\bigcirc$ & $\bigcirc$ & $\bigcirc$ & $\bigcirc$ & $\bigcirc$ & $\bigcirc$ & $\bigcirc$ & $\bigcirc$ & $\bigcirc$ & $\bigcirc$ \\
& OT & $7: 00$ & $8: 00$ & $9: 00$ & $9: 00$ & $8: 00$ & $8: 00$ & $7: 30$ & $9: 00$ & $8: 30$ & $9: 00$ & $9: 00$ & $10: 30$ \\
& CN & 1 & 1 & 1 & 1 & 1 & 1 & 1 & 1 & 1 & 1 & 1 & 1 \\
381 & PE & $\bigcirc$ & $\bigcirc$ & & $\bigcirc$ & $\bigcirc$ & & $\bigcirc$ & $\bigcirc$ & $\bigcirc$ & & $\bigcirc$ & $\bigcirc$ \\
& OT & $8: 00$ & $14: 30$ & $\mathrm{NE}$ & $8: 30$ & $14: 00$ & $\mathrm{NE}$ & $7: 30$ & $10: 00$ & $16: 00$ & $\mathrm{NE}$ & $8: 00$ & $9: 30$ \\
& $\mathrm{CN}$ & 1 & 1 & $\mathrm{P}$ & 2 & 2 & $\mathrm{P}$ & 3 & 3 & 3 & $\mathrm{P}$ & 4 & 4 \\
448 & PE & $\bigcirc$ & $\bigcirc$ & $\bigcirc$ & & $\bigcirc$ & $\bigcirc$ & $\bigcirc$ & & & $\bigcirc$ & $\bigcirc$ & $\bigcirc$ \\
& OT & $8: 00$ & $10: 00$ & $16: 00$ & $\mathrm{NE}$ & $7: 30$ & $9: 30$ & $12: 00$ & $\mathrm{IN}$ & $\mathrm{NE}$ & $7: 30$ & $10: 0015: 30$ \\
& $\mathrm{CN}$ & 1 & 1 & 1 & $\mathrm{P}$ & 2 & 2 & 2 & 2 & $\mathrm{P}$ & 3 & 3 & 3 \\
470 & PE & $\bigcirc$ & $\bigcirc$ & $\bigcirc$ & $\bigcirc$ & & $\bigcirc$ & $\bigcirc$ & $\bigcirc$ & $\bigcirc$ & & $\bigcirc$ & $\bigcirc$ \\
& OT & $6: 00$ & $9: 00$ & $10: 30$ & $15: 00$ & $\mathrm{NE}$ & $\mathrm{E}$ & $8: 00$ & $9: 00$ & $10: 00$ & $\mathrm{IN}$ & $11: 3015: 30$ \\
& $\mathrm{CN}$ & 1 & 1 & 1 & 1 & $\mathrm{P}$ & 2 & 2 & 2 & 2 & 2 & 2 & 2 \\
\hline
\end{tabular}

PE, $O$ : Present egg ; OT : Oviposition time ; $\mathrm{CN}$ : Clutch number ;

NE : No egg ; IN : Assumption of internally laid egg ;

$\mathrm{E}$ : Egg was present, but the time was not recorded; P : Pause.

The multiphasic model of Koops and Grossman (1992) was used to take into account these characteristics of egg production in laying hens. The model was as follows ;

$$
Y_{t}=1+\frac{t-\delta(c-1)}{(24+\lambda)}
$$

where $Y_{t}$ is cumulative number of eggs at time $t$ (in hour), $\lambda$ is average intra-clutch lag of oviposition time in hour (LAG), which is the difference between biological rhythm of ovulation-oviposition cycle and daily rhythm, $\delta>0$ is average delay of pause day between clutches (DELAY), which is the deviation in hour between the length of pause day and daily length, and $c$ is the sequence number of the clutch $(c=$ $1,2,3 \cdots)$.

The model can be modified to adjust for internal laying as follows ;

$$
Y_{t}=1+\frac{t-\delta(c-1)}{(24+\lambda)}-i
$$

where $i$ is cumulative number of internally laid eggs. Other variables were the same as defined in equation [1]. $\operatorname{LAG}(\lambda)$ and $\operatorname{DELAY}(\delta)$ characteristics in this study were estimated by equation [2].

Data were analyzed by GLM procedure of SAS (SAS Institute, 1985) with mean separation according to Duncan's multiple-range test. Simple correlations of LAG and DELAY with other clutch characteristics were also calculated by using SAS.

The information of clutch characteristics obtained from stages 1 and 2 was used to predict total egg number of individual hens for 270 and 360 days of egg production periods. The accuracy of prediction was determined by simple correlation between the predicted and actual number of eggs. 


\section{Results}

Means and standard deviations of clutch characteristics are presented in Table 3. Mean of LAG ranged from 0.97 to 1.05 (equal to 58.2 minutes and 63 minutes, respective1y) in high line and from 1.26 to 1.44 (equal to 75.6 minutes and 86.4 minutes, respectively) in low line. No significant differences between stages were observed for LAG in both lines, whereas there were significant differences between stages for other characteristics in both lines. Mean of DELAY significantly increased from 16.19 hours in stage 1 to 18.99 hours in stage 4 for high line, and from 16.31 hours in stage 1 to 17.94 hours in stage 4 for low line. IP also markedly increased from $5.8 \%$ to $15.0 \%$ in stages 1 and 4 , respectively for high line, and from $4.0 \%$ to $8.5 \%$ in stages 1 and 4 , respectively for low line. The difference in the number of clutches between stages was about 1 for both lines. CL and CS significantly decreased as stage increrased. The longest CL was found in stage 1 with 191.9 and 152.9 hours for high and low lines, respectively, gradually decreasing to 141.1 and 133.8 hours, respectively for high and low lines in stage 4. Consequently, the numbers of eggs laid within a clutch in stage 1 were 7.2 and 5.6 eggs for high and low lines, respectively, and 4.3 and 4.4 eggs for high and low lines, respectively in stage 4 . The comparisons between lines showed that LAG values in high line were significantly shorter than those in low line for all stages. Significant differences between lines for DELAY were found in stages 2, 3 and 4. IP in high line was significantly greater than that in low line in stages 1,3 and 4 . There were significant differences between lines for $\mathrm{CN}$ in stages 1 and 2. No significant differ-

Table 3. Means \pm standard deviations of clutch characteristics by lines and stages

\begin{tabular}{|c|c|c|c|c|c|c|c|}
\hline \multirow{3}{*}{ Characteristic } & \multirow{3}{*}{ Line } & \multicolumn{6}{|c|}{ Observation stage } \\
\hline & & \multicolumn{2}{|l|}{1} & \multicolumn{2}{|r|}{2} & \multirow{2}{*}{$\frac{3}{\text { Mean } \pm S D}$} & \multirow{2}{*}{$\frac{4}{\text { Mean } \pm S D}$} \\
\hline & & Mean \pm & $=S D$ & Mean & $\mathrm{n} \pm \mathrm{SD}$ & & \\
\hline \multirow[t]{2}{*}{ LAG (hour) } & $\mathrm{H}$ & $0.97^{\mathrm{a}} \pm$ & 0.74 & $1.01^{\mathrm{a}}=$ & $\pm \quad 0.71$ & $1.00^{\mathrm{a}} \pm 0.67$ & $1.05^{\mathrm{a}} \pm 0.73$ \\
\hline & $\mathrm{L}$ & $1.44^{\mathrm{a}} \pm$ & $1.01^{* *}$ & $1.30^{\mathrm{a}}=$ & $\pm 0.78^{* *}$ & $1.26^{\mathrm{a}} \pm 0.83^{*}$ & $1.42^{\mathrm{a}} \pm 0.95^{* *}$ \\
\hline DELAY & $\mathrm{H}$ & $16.19^{\mathrm{b}} \pm$ & 5.61 & $18.00^{\mathrm{a}}=$ & $\pm \quad 3.73$ & $18.79^{\mathrm{a}} \pm 2.23$ & $18.99^{\mathrm{a}} \pm 2.25$ \\
\hline (hour) & $\mathrm{L}$ & $16.31^{\mathrm{c}} \pm$ & 4.44 & $16.74^{\mathrm{bc}}=$ & $\pm 4.21^{*}$ & $17.71^{\mathrm{ab}} \pm 3.09^{* *}$ & $17.94^{\mathrm{a}} \pm 3.11^{* *}$ \\
\hline \multirow[t]{2}{*}{$\operatorname{IP}(\%)$} & $\mathrm{H}$ & $5.82^{\mathrm{c}} \pm$ & 7.39 & $9.92^{\mathrm{b}}=$ & \pm 12.27 & $14.35^{\mathrm{a}} \pm 15.12$ & $15.03^{\mathrm{a}} \pm 14.26$ \\
\hline & $\mathrm{L}$ & $4.03^{\mathrm{b}} \pm$ & $6.58^{*}$ & $8.11^{\mathrm{a}}=$ & \pm 12.22 & $8.16^{\mathrm{a}} \pm 9.26^{* *}$ & $8.51^{\mathrm{a}} \pm 10.46^{* *}$ \\
\hline \multirow[t]{2}{*}{$\mathrm{CN}$} & $\mathrm{H}$ & $3.79^{\mathrm{b}} \pm$ & 1.46 & $4.56^{\mathrm{b}}=$ & \pm 1.85 & $7.98^{\mathrm{ab}} \pm 1.62$ & $5.38^{\mathrm{a}} \pm 1.66$ \\
\hline & $\mathrm{L}$ & $4.56^{\mathrm{ab}} \pm$ & $1.72^{* *}$ & $4.15^{\mathrm{b}}=$ & $\pm 1.82^{*}$ & $5.38^{\mathrm{b}} \pm 1.74$ & $5.93^{\mathrm{a}} \pm 1.85^{*}$ \\
\hline \multirow[t]{2}{*}{ CL (hour) } & $\mathrm{H}$ & $191.90^{\mathrm{a}} \pm 1$ & 29.62 & $189.79^{b}=$ & \pm 113.30 & $155.84^{\mathrm{b}} \pm 62.45$ & $141.09^{b} \pm 50.44$ \\
\hline & $\mathrm{L}$ & $152.89^{\mathrm{ab}} \pm$ & $99.96^{*}$ & $165.38^{\mathrm{a}}=$ & \pm 111.26 & $147.59^{\mathrm{ab}} \pm 77.62$ & $133.80^{\mathrm{b}} \pm 78.22$ \\
\hline \multirow[t]{2}{*}{ CS (egg) } & $\mathrm{H}$ & $7.20^{\mathrm{a}} \pm$ & 5.71 & $6.50^{\mathrm{a}}=$ & $\pm \quad 4.60$ & $4.86^{\mathrm{b}} \pm 2.50$ & $4.30^{\mathrm{b}} \pm 2.09$ \\
\hline & $\mathrm{L}$ & $5.64^{\mathrm{a}} \pm$ & $4.47^{*}$ & $5.67^{\mathrm{a}}=$ & $\pm \quad 4.62$ & $4.97^{\mathrm{ab}} \pm 2.91$ & $4.40^{\mathrm{b}} \pm 2.99$ \\
\hline
\end{tabular}

IP : Rate of internal laying; $\mathrm{CN}$ : The number of clutches; $\mathrm{CL}:$ Average length of clutches ; CS : Average size of clutches.

abc: Means within row with no commom superscripts are significantly different $(p<0.05)$.

Significant difference of means between lines $\left({ }^{*}: \mathrm{p}<0.05,{ }^{* *}: \mathrm{p}<0.01\right)$. 
Table 4. Correlations of LAG, DELAY with rate of internal laying (IP), the number of clutches $(\mathrm{CN})$, average length of clutches (CL) and average size of clutches (CS)

\begin{tabular}{|c|c|c|c|c|c|c|}
\hline & Stage & Line & IP & $\mathrm{CN}$ & $\mathrm{CL}$ & $\mathrm{CS}$ \\
\hline \multirow{8}{*}{ LAG } & 1 & $\mathrm{H}$ & -0.10 & $0.77^{* *}$ & $-0.61^{* *}$ & $-0.59^{* *}$ \\
\hline & & $\mathrm{L}$ & -0.14 & $0.72^{* *}$ & $-0.55^{* *}$ & $-0.53^{* *}$ \\
\hline & 2 & $\mathrm{H}$ & 0.07 & $0.73^{* *}$ & $-0.56^{* *}$ & $-0.60^{* *}$ \\
\hline & & $\mathrm{L}$ & $-0.26^{* *}$ & $0.83^{* *}$ & $-0.62^{* *}$ & $-0.57^{* *}$ \\
\hline & 3 & $\mathrm{H}$ & $-0.24^{* *}$ & $0.74^{* *}$ & $-0.66^{* *}$ & $-0.54^{* *}$ \\
\hline & & L & $-0.24^{*}$ & $0.71^{* *}$ & $-0.56^{* *}$ & $-0.57^{* *}$ \\
\hline & 4 & $\mathrm{H}$ & $-0.37^{* *}$ & $0.72^{* *}$ & $-0.62^{* *}$ & $-0.44^{* *}$ \\
\hline & & $\mathrm{L}$ & $-0.26^{*}$ & $0.64^{* *}$ & $-0.53^{* *}$ & $-0.51^{* *}$ \\
\hline \multirow{8}{*}{ DELAY } & 1 & $\mathrm{H}$ & $0.20^{*}$ & $0.42^{* *}$ & $-0.76^{* *}$ & $-0.77^{* *}$ \\
\hline & & $\mathrm{L}$ & $0.22^{*}$ & $0.25^{* *}$ & $-0.61^{* *}$ & $-0.63^{* *}$ \\
\hline & 2 & $\mathrm{H}$ & -0.07 & 0.07 & $-0.40^{* *}$ & $-0.38^{* *}$ \\
\hline & & $\mathrm{L}$ & 0.19 & 0.14 & $-0.47^{* *}$ & $-0.50^{* *}$ \\
\hline & 3 & $\mathrm{H}$ & $0.30^{* *}$ & $-0.29^{* *}$ & $0.32^{* *}$ & $0.19^{*}$ \\
\hline & & $\mathrm{L}$ & 0.05 & -0.08 & -0.19 & -0.12 \\
\hline & 4 & $\mathrm{H}$ & $0.40^{* *}$ & $-0.31^{* *}$ & $0.33^{* *}$ & 0.13 \\
\hline & & $\mathrm{L}$ & 0.09 & -0.01 & $-0.26^{*}$ & $-0.20^{*}$ \\
\hline
\end{tabular}

${ }^{*}: \mathrm{p}<0.05, \quad{ }^{* *}: \mathrm{p}<0.01$

Table 5. Means and correlation coefficients of actual and predicted egg number

\begin{tabular}{|c|c|c|c|c|c|c|c|}
\hline \multirow{2}{*}{ Line } & \multirow{2}{*}{ Stage } & \multicolumn{2}{|c|}{ Actual } & \multicolumn{2}{|c|}{ Predicted } & \multicolumn{2}{|c|}{ Correlation } \\
\hline & & $\mathrm{P}_{270}$ & $\mathrm{P}_{360}$ & $\mathrm{Y}_{270}$ & $\mathrm{Y}_{360}$ & $\mathrm{r}_{\mathrm{p} 270-\mathrm{y} 270}$ & $r_{p 360-y 360}$ \\
\hline \multirow[t]{2}{*}{ High } & 1 & 204.6 & 241.2 & 217.8 & 289.8 & 0.69 & 0.63 \\
\hline & 2 & 208.8 & 247.3 & 204.7 & 272.3 & 0.69 & 0.59 \\
\hline \multirow[t]{2}{*}{ Low } & 1 & 200.4 & 239.7 & 213.7 & 284.3 & 0.66 & 0.58 \\
\hline & 2 & 209.4 & 253.2 & 205.2 & 273.1 & 0.82 & 0.46 \\
\hline \multirow[t]{2}{*}{ Total } & 1 & 202.6 & 240.5 & 215.8 & 287.2 & 0.67 & 0.60 \\
\hline & 2 & 209.1 & 250.1 & 204.9 & 272.7 & 0.75 & 0.64 \\
\hline
\end{tabular}

ences between lines for CL and CS were found in all stages except for stage 1 .

The relationships of LAG and DELAY with other clutch characteristics are shown in Table 4. Negative and low correlations between LAG and IP were found, while there were positive and high correlations of LAG with CN. Medium and negative correlations of LAG with CL and CS were estimated. The correlations of DELAY with IP and $\mathrm{CN}$ were generally low in all stages of both lines. Significant and high correlations between DELAY and CL and CS were found in stage 1 for both lines, while low correlations between those were found in other stages for both lines.

Means of annual egg number for individual hens predicted by equation [2] and correlations with actual number of eggs are reflected in Table 5. The differences 
between the numbers of eggs predicted by using clutch characteristics in stage 1 and actual values for the 270-day-EP were 13 14 eggs with correlation coefficients of 0.66 $\sim 0.69$, and for the 360-day-EP were 43 49 eggs with correlation coefficients of $0.58 \sim$ 0.63. The differences between actual and predicted number of eggs were smaller in stage 2 than in stage 1 for both the 270-day-EP and 360-day-EP. The correlation coefficients in 270-day-EP prediction were higher than that in 360-day-EP prediction for both lines in two stages.

\section{Discussion}

Egg production of individual hens can be characterized by the multiphasic model of Koops and Grossman (1992) in which total egg number at time $\mathrm{t}$ (in hour) of egg production is a function of intra-clutch lag of oviposition time and delay of pause day between clutches. In case internal laying occurs, the multiphasic model can be modified to include internal laying characteristic. Intra-clutch lag of oviposition time estimated by the modified multiphasic model in the present study did not vary over the entire laying period in both high and low lines. The result of this study agreed with the hypothesis of Koops and Grossman (1992) that mean lag of ovipostion time within clutch adjusted for internal laying was a constant over laying period. However, significant differences in intra-clutch oviposition intervals between laying cycles of the first and second years were reported by LILLPERS and WILHELMSON (1993).

LAG in high line was significantly shorter than that in low line for all stages. It may be that the follicle of the hens in high line seems to reach the maturation size for ovulation faster than that in low line. The other possibility is that the time spent by an ovum in the oviduct for egg formation is longer in low line than in high line. Further, if LAG is the best indicator of egg production, this result should show that egg production in high line is greater than that in low line. However, the rate of internal laying (IP) was significantly higher in high line than in low line in all stages except for stage 2. This resulted in insignificant difference in hen-day egg production between lines.

DELAY in both lines was longer than 16 hours, suggesting that the length of pause day was longer than 40 hours. The significant differences in DELAY between stages and lines might be due to the differences in responses of chickens of two lines to different stages of laying period. DELAY has been suggested to be determined by environment, especially by light/dark cycle. An increase in photoperiod may result in an increase of DELAY of ovulation unless selection for reduction of LAG or expansion of clutch size is conducted.

High and positive correlations between LAG and CN were found in both high and low lines, and consequently, the correlations between LAG and CL and CS were negative and medium in high and low lines. LAG is expected to have a negative correlation with total number of eggs, indicating the same results reported by Koops and Grossman (1992). A negative genetic correlation between mean intra-clutch oviposition interval and egg production was reported by MCCLUNG et al. (1976), SHELDON et al. (1984) and Yoo et al. (1988). Therefore, the correlation between LAG and total 
number of eggs is expected to be genetically negative. However, no significant relationship between LAG and clutch size in Japanese quail was found by AGGREY et al. (1993), and no correlation between intra-clutch oviposition interval in the first year of egg production period and egg production in the second year was shown by LILLPERS and WilheLmSon (1993). Negative correlation between LAG and IP resulted from the inclusion of internal laying in the clutch definition where internal laying was considered as a normal process of ovulation. This phenomenon can be eliminated by the exclusion of internal laying from the clutch and consideration of intra-sequence lag of oviposition time.

The correlation coefficients between actual and predicted values for 270-day-egg production were higher than that for 360 day-egg-production in all stages of two lines. This shows that the accuracy of prediction for the entire production period is lower than that for the main production period, because at the end of the egg production period the rate of internally laid eggs increased rapidly. Prediction accuracy can be also increased by increasing observation periods of oviposition time.

The present multiphasic model may be a potential tool to predict egg production for individual hens with a relatively high egg production as a result of genetic selection based on conventional traits. Although LAG parameter was not significantly different over the entire laying period, the predicted value $\left(Y_{t}\right)$ depends on internal laying, clutch number, and partly on delay of pause day. Internal laying has been determined to be a variable over the laying period (GILBERT and WOoD-Gush, 1971). Further studies on the methods for predicting internal laying characteristic would be needed to increase the accuracy of prediction of egg production by the multiphasic model.

\section{Acknowledgment}

The authors wish to thank Wilson A. Cerbito for reading the manuscript.

\section{References}

Adams, C.J. and D.D. Bell (1980) Predicting poultry egg production. Poultry Science, 59 : 937-938. AgGrey, S.E., C.R. Nichols and K.M. Cheng (1993) Multiphasic analysis of egg production in Japanese quail. Poultry Science, $72: 2185-2192$.

Gavora, J.S., L.E. LILJEDAhL, I. MCMilLan and K. Ahlen (1982) Comparison of three mathematic models of egg production. British Poult. Science, 23 : 339-348.

GILBERT, A.B. and D.G.M. WOOD-GUSH (1971) Ovulatory and ovipository cycles. pages 1353-1378 in : Physiology and biochemistry of the domestic fowl. D.J. BeLL and B.M. FreEMAN (eds). New Yolk, Academic press.

Koops, W.J. and M. Grossman (1992) Characterization of poultry egg production using a multiphasic approach. Poultry Science, $71: 399-405$.

Lillpers, K. and M. Wilhelmson (1993) Age-dependent changes in oviposition pattern and egg production traits in domestic hen. Poultry Science, 72 : 2005-2011.

MCClung, M.R., Albert, B.S. WANG and W.T. Jones (1976) Response to selection for time interval between oviposition time in the hen. Poultry Science, $55:$ 160-171.

McMillan, I., M. Fitz-EARLE and D.S. RobSon (1970a) Quantitative genetics of fertility I. Lifetime of egg production of Drosophia melanogaster. Genetics 65 : 349-353.

McMillan, I., M. Fitz-Earle, L. Butler and D.S. Robson (1970 b) Quantitative genetics of fertility II. Lifetime of egg production of Drosophia melanogaster. Genetics $65: 355-369$. 
McMillan, I., R.S. Gowe., J.S. Gavora and R.W. Fairfull (1986) Prediction of annual production from part record egg production in chickens by three mathematical models. Poultry Science, $65: 817-822$.

McNally, D.H. (1971) Mathematic model for poultry egg production. Biometrics 27 : 735-738.

Mitsumoto, T. and S. Miyoshi (1989) Responses to divergent selection for high and low yolkalbumen ratio and relaxation of selection in White Leghorn. Proceeding of the 6th Internatiol. Congress of SABRAO, Tokyo. II. 893-896.

Nalbandov, A.V. and H. Opel (1974) Egg laying. Pages 394-408 in : Animal agriculture. H.H. Cole. ed. Freeman and Co., New yolk, NY.

SAS Institute (1985) SAS ${ }^{\circledR}$ User's guide : Statistics. Version 5 edition. SAS Institute Inc., Cary, NC. SHELdon, B.L., B.H. Yoo and R.N. Podger (1984) Increasing egg yield under normal light cycles by selecting for short interval between eggs under continuous light. Ann. Agric. Henn. 23 : $216^{-}$ 225 (CSIRO Div. of Anim. production, Prospect, NSW, Australia).

Wood, P.D.P. (1967) Algebraic model of the lactation curve in cattle. Nature (London) $216: 164-165$.

YANG, N., C. WU and I. MCMILlaN (1989) New mathematical model of poultry egg production. Poultry Science, 68 : 476-481.

Yoo, B.H., B.L. Sheldon and R.N. Podger (1988) Genetic parameters for oviposition time and interval in a White Leghorn population of recent commercial origin. British Poultry Science, 29 : 627-637.

\section{鶏の産卵に対する Multiphasic モデルの適用}

$$
\text { ルックキィウ ミン・三好俊三・光本孝次 }
$$

帯広畜産大学畜産学部畜産管理学科 北海道帯広市 080

鶏の産卵にはクラッチが存在する。本研究ではそのク ラッチに関連する形質の産卵期間における変異性を検討 した。また，KOOPS とGROSSMAN（1992）が提案した Multiphasic モデルを用い，卵墜を考慮して個体の年間 総産卵数の予測を試みた。

卵黄・卵白比の高および低力向に選抜育種された鶏群 （高系統；135 羽，低系統；123 羽）を用い, 放卵時間を 4 つの時点（各々約 30 日間）で観察した。分析に用いたク ラッチ形質は卵丞率 (IP), クラッチ数 $(\mathrm{CN})$, クラッチ 長 (CL)，クラッチサイズ (CS) および Multiphasic モ デルから推定した LAG（クラッチ内の放卵間隔と日長 との差）とDELAY（休産日の長さと日長との差）であ る。

LAGには観察期間で両系統とも有意差が認められな かったが，DELAY は産卵の進行に伴って有意に増加し た。また, IP と CN あ増加傾向にあった。それに対し, CL およびCS は減少傾向にあった。一方，LAG は高系
統が有意に短い時間で推移し，高い産卵が予測された が, 卵墜率は高系統が有意に高い值で推移し, 実際の産 卵数は同等であった。

LAG と CN とには正の相対的に高い相関関係が存在 し，CL および CS 間には中位の負の相関係数が推定さ れた。このことは放卵間隔の短い個体が高い産卵を示唆 するものである。卵陮むクラッチに含めたため, LAG と IP には負の相関係数が推定された。

初産から 120 日および 188 日での観察期間から推定し たクラッチ形質を用い，270日間および 360 日間の産卵 数を予測した場合，いずれも過大（約 35 卵）となった。 予測值と実測值との相関係数は $0.6 \sim 0.8$ が推定された。 これらのことより，Multiphasic モデルを用いて個体の 年間産卵数をある程度予測が可能であると推察した。

(家离会誌, 32:161-168, 1995)

キーワード：マルチファジックモデル クラッチ形質 予测産卵数 放卵時間 産卵鶏 